Jurnal Teknologi Informasi dan Manajemen

Edisi 1, Volume 1, Bulan Juli, Tahun 2018. E-ISSN 2622-2647

\title{
EPIC MODEL: PENGUKURAN EFEKTIVITAS IKLAN KULINER MELALUI SOSIAL MEDIA INSTAGRAM @KULINERBANDUNG SEBAGAI MEDIA PROMOSI
}

\author{
Widya Sastika \\ Program Studi D3 Manajemen Pemasaran, Fakultas IImu Terapan, Universitas Telkom \\ wiedyasastika@tass.telkomuniversity.ac.id
}

\begin{abstract}
One other thing that makes the Internet different as mass media with other traditional media is its capacity to combine trade with access to information and entertainment. The Internet is completely different from other traditional media. One step that could be taken is by doing marketing and advertising. Instagram as one of the social media that is now has evolved and has many followers. Instagram raises a new feature that is Instagram ads service. Instagram ads service is a feature of advertising that can advertise directly by business people. The system used in Instagram ads service is a selfserve system. Knowing the rapid development of advertising in social media, especially Instagram, needing to know how effective advertising done in Instagram by using EPIC method. The object is culinary ads in Instagram @kulinerbandung. Respondents in this study conducted by spreading questionnaires to 400 respondents in the city of Bandung. Dimensions in measuring advertising effectiveness are Empathy, Persuasion, Impact, and Communication. Based on consumer perception toward Empathy dimension average score obtained at 3.65, Persuasion dimension obtained at 3.66, Impact dimension obtained at 3.56, and Communication dimension obtained at 3.45 so overall obtained EPIC value at 3.58. EPIC score at 3.58 indicates that culinary advertising through social media Instagram @kulinerbandung considered very effective.
\end{abstract}

Keywords: EPIC model, effectiveness, Instagram, @kulinerbandung

Abstrak: Salah satu hal lain yang berbeda dari Internet dengan media tradisional adalah kemampuan untuk menyatukan akses informasi dan hiburan. Hal yang bisa dimanfaatkan adalah melakukan pemasaran dan periklanan. Instagram merupakan salah satu sosial media yang sekarang sedang berkembang dan mempunyai banyak pengikut, Media sosial Instagram memunculkan fitur baru yaitu layanan Instagram ads. Layanan Instagram ads adalah fitur layanan iklan yang bisa memasang iklan secara langsung oleh para pelaku bisnis. Sistem yang digunakan pada layanan Instagram ads adalah sistem swalayan atau self-serve. Mengetahui pesatnya perkembangan periklanan di sosial media, terutama Instagram maka perlu diketahui seberapa efektif iklan yang dilakukan di media online Instagram menggunakan metode EPIC. Objek yang diteliti adalah Iklan kuliner yang ada di Instagram @kulinerbandung. Responden pada penelitian ini dilakukan dengan menyebar kuesioner kepada 400 responden di kota Bandung. Dimensi untuk mengukur efektivitas iklan adalah Empathy, Persuasion, Impact, and Communication. Berdasarkan persepsi konsumen terhadap dimensi Empathy skor rata-rata yang didapat sebesar 3,65, dimensi Persuasion sebesar 3,66, dimensi Impact sebesar 3,56, dan dimensi Communication sebesar 3,45 sehingga diperoleh nilai EPIC rate 3,58 . Nilai EPIC rate 3,58 tersebut menunjukkan bahwa iklan kuliner melalui sosial media Instagram @kulinerbandung dinilai sangat efektif.

Kata Kunci: metode EPIC, efektivitas, Instagram, @kulinerbandung 


\section{Jurnal Teknologi Informasi dan Manajemen \\ Edisi 1, Volume 1, Bulan Juli, Tahun 2018. E-ISSN 2622-2647}

\section{PENDAHULUAN}

Perkembangan teknologi dan internet (Inter Connected Network) menjadi salah satu media yang digunakan dalam berbagai keperluan dan sudah semakin berkembang. Salah satu contoh dari kegunaan teknologi yang memanfaatkan internet adalah perdagangan elektronik atau biasa disebut e-commerce, yang merupakan sebuah fasilitas yang digunakan untuk melakukan transaksi pembelian, penjualan, baik produk maupun jasa yang dilakukan dengan media komputer yang terhubung kedalam sebuah jaringan internet [1].

Akses terhadap informasi dan hiburan membuat Internet terlihat sangat berbeda sebagai media massa dengan media tradisional. Promosi perdagangan (promotion commerce) menghubungkan antara penjual dengan pembeli potensial), penerimaan iklan (accepting advertising), dan penyediaan konten online (providing online content) merupakan tiga sumber pontensial penerimaan di Internet [2].

Pada tahun 2015, belanja iklan di media US\$11,39 miliar, iklan digital hanya sebsar US\$ 830 juta atau Rp.11,2 triliun jika kurs Rp 13.500. E-marketer meramalkan iklan digital akan berkembang lima tahun yang akan datang. Pada tahun berikutnya yaitu tahun $2016,10 \%$ belanja iklan di Indonesia akan berada pada iklan digital. Rasio akan mencapai $25 \%$ pada tahun 2019. Menurut e-Marketer, akhir tahun 2019 nanti iklan digital akan lebih banyak dilakukan kearah mobile. Pada tahun 2016 mobile digital terus meningkat, dan tiga tahun lagi akan mengalahkan Argentina, Spanyol, Brazil, dan India [3].

Survei DailySocial dengan tajuk Laporan Perilaku Konsumen Digital 2016 yang terbit pada Agustus 2016 lalu adalah survei yang menyoroti perubahan perilaku konsumen di berbagai sektor bisnis digital. Ada banyak hal menarik yang ditemukan, salah satunya terkait dengan dampak iklan terhadap pengambilan keputusan untuk berbelanja online. Berdasarkan data survei ditemukan bahwa iklan Facebook, Instagram, dan Google adalah iklan yang paling berperan dalam mendorong keputusan masyarakat untuk berbelanja online. Dunia $e-$ commerce memang tengah menjadi sektor paling bergairah di bisnis digital Indonesia dengan potensinya yang masih besar. Meski masih ada banyak tantangan untuk diselesaikan, namun e-commerce Indonesia juga tidak perlu dicemaskan pertumbuhannya [4].

Media sosial Instagram memunculkan fitur baru yaitu layanan Instagram ads. Layanan Instagram ads adalah fitur layanan iklan yang bisa membuat para pelaku bisnis memasang iklan secara langsung di Instagram. Sistem yang digunakan pada layanan Instagram ads adalah sistem swalayan atau self-serve. Fitur iklan yang digunakan oleh layanan Instagram ads sama dengan yang digunakan Facebook, hal ini membuat iklan yang ditayangkan di Instagram dapat dilihat oleh penggunanyaa sesuai dengan target. Selain itu, pengiklan dapat menggunakan banyak format yang disediakan Instagram ads sesuai dengan jenis bisnisnya. Ribuan bisnis di seluruh dunia menggunakan etalasenya Menurut pihak Instagram. Hal tersrbut mendorong Instagram untuk membuat sebuah layanan pengiklanan secara langsung di Instagram. Iklan seperti foto, video, marquee atau teks berjalan, serta menyajikan fitur optimasi untuk mengatur dan meningkatkan kinerja kampanye produk disediakan oleh Instagram ads [5].

Instagram menyatakan bahwa yang memasang iklan foto dan video di aplikasi tersebut berkembang dengan pesat. Lima ratus ribu pemasang iklan yang dimiliki oleh Instagram. Diperkirakan, $\$ 1,5$ milyar yang diperoleh oleh Instagram yang terus meningkat pada tahun 2018 menjadi \$5 milyar. Pada saat ini, aplikasi Instagram digunakan oleh 600 juta pelanggan. Selama enam bulan terakhir 100 juta pengguna bergabung. Banyak 


\section{Jurnal Teknologi Informasi dan Manajemen Edisi 1, Volume 1, Bulan Juli, Tahun 2018. E-ISSN 2622-2647}

pembaharuan fitur yang dilakukan oleh Insatagram seperti menambahkan fitur bookmark dimana pelanggan bisa melihat unggahan yang disukai dan telah ditandai. Instagram diharapkan menjadi sarana melihat jejak visual setiap hari di belahan dunia menurut Chief Executive Officer (CEO) Instagram Kevin Systrom [6].

Mengetahui pesatnya perkembangan periklanan di media online, terutama Instagram maka perlu diketahui seberapa efektif iklan yang dilakukan di media online Instagram. Adapun tujuan dalam penelitian ini adalah mengetahui seberapa efektif iklan di media online Instagram akun @kulinerbandung menggunakan metode EPIC.

\section{TINJAUAN PUSTAKA}

\subsection{Definisi Periklanan}

Periklanan (advertising) merupakan sebuah proses komunikasi massa yang melibatkan sponsor tertentu, seperti pemasangan iklan (pengiklan) dengan membayar sebuah jasa media massa atas penyiaran iklannya, misalnya melalui program siaran televisi [7]. Periklanan merupakan sebuah komunikasi komersil ataupun nonpersonal yang akan disampaikan melalui media massa, contohnya kendaraan umum, reklame luar ruangan, direct mail, majalah, koran, radio dan televisi [8].

\subsection{EPIC Model}

Empathy, Persuasion, Impact and Communication atau EPIC Model merupakan sebuah alat untuk mengukur efektivitas iklan menggunakan pendekatan komunikasi yang dikembangkan oleh AC Nielsen [9]. Adapun dimensi-dimensi yang terdapat dalam EPIC model adalah: 1) Dimensi Empati (empathy) adalah keadaan mental seseorang untuk mengidentifikasikan dirinya atau merasa dirinya pada keadaan perasaan atau pikiran yang sama dengan orang atau kelompok lain. 2) Dimensi Persuasi (persuasion) merupakan perubahan kepercayaan, sikap, dan keinginan berperilaku yang disebabkan oleh suatu komunikasi promosi. 3) Dimensi Dampak (impact) merupakan hal yang diinginkan dari hasil iklan yaitu kuantitas pengetahuan produk (product knowledge) yang dapat dicapai konsumen melalui tingkat keterlibatan (involvement) konsumen dengan produk atau proses pemilihan. 4) Dimensi Komunikasi (communication), memberikan informasi tentang kemampuan konsumen dalam mengingat pesan utama yang disampaikan, pemahaman konsumen, serta kekuatan kesan yang ditinggalkan pesan tersebut. Peningkatan Pelayanan tetap harus dilakukan walaupun Efektivitas Iklan sudah efektif [10].

\section{METODE PENELITIAN}

Populasi adalah suatu kumpulan subjek, variabel, konsep atau fenomena untuk bisa ditarik menjadi beberapa kesimpulan. Populasi bukan hanya orang, tetapi juga objek dan benda alam lain. Populasi dalam penelitian ini adalah Masyarakat kota Bandung yang mempunyai akun Instagram dan pernah melihat iklan yang ditampilkan di Instagram @kulinerbandung [11]. Teknik pengambilan sampel dalam penelitian ini adalah nonprobability sampling. Metode sampling yang digunakan dalam penelitian ini adalah purposive sampling. Purposive sampling adalah teknik penentuan sampel dengan pertimbangan tertentu [12]. Jumlah populasi dalam penelitian ini tidak diketahui secara pasti jumlahnya, maka teknik pengambilan sampel yang digunakan adalah rumus Bernoulli [13]. Batas tingkat kesalahan untuk penelitian sosial adalah 10\% [14], tetapi pada penelitian ini diambil tingkat kesalahan $5 \%$ sehingga apabila dihitung dengan menggunakan rumus Bernoulli, diperoleh sampel penelitian sebanyak 400 orang. 


\section{Jurnal Teknologi Informasi dan Manajemen \\ Edisi 1, Volume 1, Bulan Juli, Tahun 2018. E-ISSN 2622-2647}

\section{PEMBAHASAN DAN HASIL PENELITIAN}

\subsection{Karakteristik Responden}

Adapun data-data karakteristik respondennya adalah Karakteristik responden berdasarkan Jenis kelamin adalah perempuan sebesar $64 \%$ dan laki-laki 36\%. Usia $<20$ tahun sebesar $24 \%$, antara $20-30$ tahun sebesar $57 \%, 31-40$ tahun sebesar $13 \%$, dan $>40$ tahun sebesar $6 \%$. Berdasarkan pekerjaan, responden yang paling banyak adalah responden yang bekerja sebagai Mahasiswa 35\%, Pelajar 21\%, Karyawan Swasta 16\%, Wiraswasta $13 \%$, dan tidak bekerja sebesar 5\%. Adapun pendapatan sebesar Rp. 2.000.001 - Rp. 5.000 .000 sebesar $36 \%$.

\subsection{Validitas dan Reliabilitas}

Alat ukur yang digunakan harus valid untuk mendapatkan data valid. Instrumen tersebut dapat digunakan untuk mengukur apa yang seharusnya diukur [15]. Kuesioner dirancang untuk mengetahui persepsi konsumen terhadap iklan yang ada di media sosial Instagram yang ada di akun @kulinerbandung. Dari kuesioner tersebut didapat data untuk mengetahui efektivitas iklan berdasarkan dimensi Empathy, Persuasion, Impact dan Communication. Kuesioner dilakukan pretest validitas dan reliabilitas terlebih dahulu sebelum disebar ke responden.

Berdasarkan hasil pengolahan data SPSS dengan 12 atribut dinyatakan bahwa seluruh atribut dianggap valid karena $r$ hitung $>r$ table, dan juga dianggap reliabel karena nilai Cronbach's Alpha $>0.6$ yaitu 0.831 .

\subsection{Analisis Data Pemetaan}

Skala yang digunakan pada penelitian ini yaitu: (1). Sangat Tidak Efektif, (2). Tidak Efektif, (3). Efektif, (4). Sangat Efektif. Rentang skala dapat dilihat pada Tabel 1.

Tabel 1

Rentang skala

\begin{tabular}{|c|c|c|}
\hline Bobot (B) Skala & Skor & \multirow{2}{*}{ Rentang Skala } \\
\hline Paling Besar & 4 & \multirow{2}{*}{$(4-1) / 4=0.75$} \\
\hline Paling Kecil & 1 & \\
\hline
\end{tabular}

Sumber: Diolah oleh penulis (2018)

Selanjutnya dilakukan tabulasi berdasarkan dimensi:

\section{Dimensi Empathy}

Berdasarkan hasil persepsi konsumen terhadap dimensi Empathy:

Tabel 2

Skor rata-rata empathy

\begin{tabular}{|l|c|c|c|c|c|c|c|}
\hline \multirow{2}{*}{ Atribut } & Bobot & $\begin{array}{c}\text { Jumlah } \\
\text { Respon- } \\
\text { den }\end{array}$ & $\begin{array}{c}\text { Bobot } \mathbf{x} \\
\text { Jumlah } \\
\text { respon- } \\
\text { den }\end{array}$ & $\begin{array}{c}\text { Jumlah } \\
\text { Respon- } \\
\text { den }\end{array}$ & $\begin{array}{c}\text { Bobot } \\
\mathbf{x} \\
\text { Jumlah } \\
\text { respon- } \\
\text { den }\end{array}$ & $\begin{array}{c}\text { Jumlah } \\
\text { Respon- } \\
\text { den }\end{array}$ & $\begin{array}{c}\text { Bobot } \mathbf{x} \\
\text { Jumlah } \\
\text { responden }\end{array}$ \\
\cline { 3 - 8 } & \multicolumn{2}{|c|}{ Empathy-1 } & \multicolumn{2}{|c|}{ Empathy-2 } & \multicolumn{2}{|c|}{ Empathy-3 } \\
\hline Sangat Efektif & 4 & 222 & 888 & 283 & 1132 & 297 & 1188 \\
\hline Efektif & 3 & 176 & 528 & 111 & 333 & 94 & 282 \\
\hline
\end{tabular}




\section{Jurnal Teknologi Informasi dan Manajemen}

Edisi 1, Volume 1, Bulan Juli, Tahun 2018. E-ISSN 2622-2647

\begin{tabular}{|c|c|c|c|c|c|c|c|}
\hline \multirow[t]{2}{*}{ Atribut } & \multirow[t]{2}{*}{ Bobot } & $\begin{array}{c}\text { Jumlah } \\
\text { Respon- } \\
\text { den }\end{array}$ & $\begin{array}{c}\text { Bobot } x \\
\text { Jumlah } \\
\text { respon- } \\
\text { den }\end{array}$ & $\begin{array}{c}\text { Jumlah } \\
\text { Respon- } \\
\text { den }\end{array}$ & $\begin{array}{c}\text { Bobot } \\
\mathbf{x} \\
\text { Jumlah } \\
\text { respon- } \\
\text { den }\end{array}$ & $\begin{array}{c}\text { Jumlah } \\
\text { Respon- } \\
\text { den }\end{array}$ & $\begin{array}{l}\text { Bobot x } \\
\text { Jumlah } \\
\text { responden }\end{array}$ \\
\hline & & \multicolumn{2}{|c|}{ Empathy-1 } & \multicolumn{2}{|c|}{ Empathy-2 } & \multicolumn{2}{|c|}{ Empathy-3 } \\
\hline Tidak Efektif & 2 & 2 & 4 & 6 & 12 & 9 & 18 \\
\hline Sangat tidak Efektif & 1 & 0 & 0 & 0 & 0 & 0 & 0 \\
\hline Total & & 400 & 1420 & 400 & 1477 & 400 & 1488 \\
\hline \multirow{2}{*}{\multicolumn{2}{|c|}{ Rata-rata }} & \multicolumn{2}{|c|}{3.55} & \multicolumn{2}{|c|}{3.69} & \multicolumn{2}{|c|}{3.72} \\
\hline & & \multicolumn{6}{|c|}{3.65} \\
\hline
\end{tabular}

Sumber: Diolah oleh penulis (2018)

Mengetahui dari Tabel 2. hasil perhitungan rata-rata skor dari Empathy 1, 2 dan 3 didapat skor sebesar 3,65, penjelasan melalui rentang skala penilaian terdapat dalam Gambar 1.

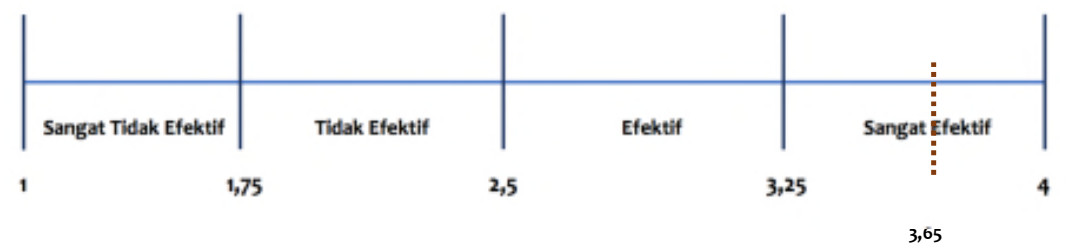

Gambar 1

Skala penilaian dimensi empathy

Sumber. Diolah oleh penulis (2018)

Dilihat dari rentang skala penilaian efektivitas iklan social media Instagram pada akun @kulinerbandung dimensi Empathy berada pada kategori Sangat Efektif.

\section{Dimensi Persuasion}

Pada dimensi Persuasion, hasil perhitungan rata-rata skor dari Persuasion 1, 2 dan 3 didapat skor sebesar 3,66, apabila dijelaskan melalui rentang skala penilaian efektivitas iklan sosial media Instagram pada akun @kulinerbandung dimensi Persuasion berada pada kategori Sangat Efektif.

\section{Dimensi Impact}

Pada dimensi Impact, didapat hasil perhitungan rata-rata skor dari Impact 1, 2 dan 3 didapat skor sebesar 3,56, apabila dijelaskan melalui rentang skala penilaian efektivitas iklan sosial media Instagram pada akun @kulinerbandung dimensi Impact berada pada kategori Sangat Efektif.

\section{Dimensi Communication}

Berdasarkan hasil persepsi konsumen terhadap dimensi Communication, didapat hasil perhitungan rata-rata skor dari Communication 1, 2 dan 3 didapat skor sebesar 3,45, apabila dijelaskan melalui rentang skala penilaian efektivitas iklan social media Instagram pada akun @kulinerbandung dimensi Communication berada pada kategori Sangat Efektif. 


\section{Jurnal Teknologi Informasi dan Manajemen \\ Edisi 1, Volume 1, Bulan Juli, Tahun 2018. E-ISSN 2622-2647}

\subsection{EPIC Rate}

EPIC rate dapat dihitung berdasarkan hasil rata-rata antara Empathy, Persuasion, Impact and Communication sebagai berikut:

$$
\begin{aligned}
\text { EPIC rate } & =(\mathrm{XE}+\mathrm{XP}+\mathrm{XI}+\mathrm{X} \mathrm{C}) / 4 \\
& =(3,65+3,66+3,56+3,45) / 4=3,58
\end{aligned}
$$

Dilihat dari rentang skala, menurut persepsi konsumen iklan yang ditayangkan di sosial media Instagram pada akun @kulinerbandung berada pada kategori Sangat Efektif sesuai dengan yang terdapat pada Gambar 2.

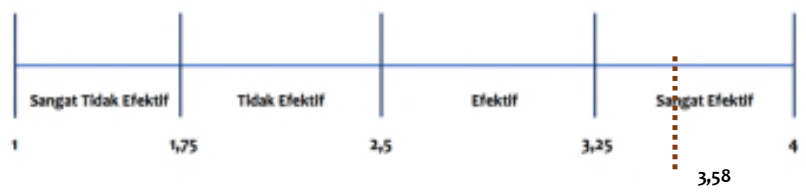

Gambar 2

Skala Penilaian Metode EPIC

Sumber. Diolah oleh penulis (2018)

\section{KESIMPULAN}

Berdasarkan hasil penelitian dapat disimpulkan, dengan mengetahui rata-rata hasil dimensi EPIC berada pada 3,58, menunjukkan bahwa iklan di sosial media Instagram pada akun @kulinerbandung menurut masyarakat kota Bandung yang memiliki akun Instagram dan pernah melihat iklan di akun @kulinerbandung sangat efektif. Banyak masyarakat Bandung yang mengetahui tempat kuliner dengan melihat akun Instagram @kulinerbandung. Untuk seterusnya akun Instagram @kulinerbandung lebih banyak menampilkan iklan mengenai kuliner yang ada di Bandung, karena sekarang wisatawan yang datang ke Bandung atau masyarakat kota Bandung sendiri, apabila ingin mencoba kuliner, mereka banyak mencari di media Internet, serta melihat review dari pelanggan yang sudah pernah mencoba kuliner tersebut.

\section{REFERENSI}

[1] Kotler, Philip and Kevin Lane Keller, 2011. Manajemen Pemasaran, Edisi 13 Jilid 1 dan 2, Alih Bahasa: Bob Sabran, Erlangga, Jakarta.

[2] Biagi, Shirley. 2010. Media/Impact: An Introduction to Mass Media. California: Wadsworth Publishing Company.

[3] Marketer Editor. Tahun 2016 akan Jadi Tahunnya Iklan Digital. 11 April 2016. www.marketeers.com.

[4] Priambada, Adjie. Survei DailySocial: Iklan facebook dan Instagram Berperan Besar dalam Mendorong Keputusan Berbelanja Online di Indonesia. 22 September 2016. www.dailysocial.id.

[5] Utomo, Riandanu Madi. Anda akan Mulai Melihat Iklan di Instagram. 09 September 2015. www.teknologi.metrotvnews.com.

[6] Bhaskara, Ign. L Adhi. Jumlah Pemasang Iklan di Instagram Bertumbuh Pesat. 16 Desember 2016. www. tirto.id.

[7] Suhandang, Kustadi. (2016) Manajemen, Kiat dan Strategi Periklanan (Edisi Revisi). Nuansa.Bandung.

[8] Lee, Monle dan Carla Johnson. (2011). Prinsip-prinsip Pokok Periklanan dalam Perspektif Global. Kencana Prenada Media Group. Jakarta.

[9] Durianto, Sugiarto dan Hendrawan.S. (2003). Inovasi Pasar Dengan Iklan Yang Efektif, PT. Gramedia Pustaka Utama Jakarta 


\section{Jurnal Teknologi Informasi dan Manajemen}

Edisi 1, Volume 1, Bulan Juli, Tahun 2018. E-ISSN 2622-2647

[10] Hanifa, Fanni Husnul. Efektivitas Layanan SMS Marketing dengan Menggunakan EPIC model (Studi Pada Pelanggan Telkomsel Kota Bandung Tahun 2016). Jurnal IImiah Ekonomi dan Manajemen STIE AL-Khairiyah (KAIZEN). Vol. 12 Januari-Juni 2016

[11] Morissan, M.A. (2012). Metode Penelitian Survey. Jakarta: Kencana.

[12] Sugiyono. (2010). Metode Penelitian Kuantitatif, Kualitatif dan R\&D. Alfabeta. Bandung.

[13] Zikmund, William G. (2010). Business Research Methods. Australia: South Western Cengage Learning

[14] Suharyadi, Purwanto, S.K. (2009). Statistika untuk Ekonomi dan Keuangan Modern Edisi 2. Jakarta: Penerbit Salemba Empat.

[15] Sugiyono. (2014). Metode Penelitian Bisnis. Alfabeta. Bandung. 